\title{
CLUSTER-BASED LOCAL ECONOMIC DEVELOPMENT (The Case of Cluster Development in Umbul Ponggok, Klaten) \\ Nunuk Dwi Retnandari' ${ }^{1}$ David Merauje ${ }^{2}$
}

\begin{abstract}
Local economic development is one of the means regional governments frequently employ to improve community welfare. However, improper management and development patterns would lead to failure in the implementation of economic development or outside communities may enjoy the benefits of economic development instead. Umbul Ponggok is a community-based tourist destination and it has, to this day, been capable of becoming a source of livelihood for most of the residents living in the area. The community's involvement at every level of the decision making process and implementation guarantees continuity in the local economy they develop. Additionally, the transparent and accountable management in place ensures the high level of trust people have. Such superior level of trust and involvement was no overnight feat, persistence and wholeheartedness of initiators along with the support of various parties (university, banking institutions, NGO, and others) made certain that the numerous issues encountered were resolved, all challenges overcome, and every opportunity taken.
\end{abstract}

Keywords: local economic development; community participation and role of stakeholders; accountability and transparency

\section{Introduction}

Local economy ${ }^{3}$ in Indonesia is deemed by many analysts as exceedingly strong and resilient against various occurring economic crises, the local economy was even considered to have saved Indonesian economy during its period of crisis in 1998 ( LPPI and Bank Indonesia, 2014). Another display of the significant role local economy has is its capacity to create added value and absorb employment. In 2016, this sector was able to absorb as much as $97.22 \%$ of available labor with the added value capacity of $60.34 \%$ in the GDP (BPS,2017).

\footnotetext{
${ }^{1}$ Lecturer of Public Administration at the Faculty of Social and Political Sciences, UGM ${ }^{2}$ Section Head of Promotion and Investment Climate at the Jayapura Municipality Office of Investment and One Stop Integrated Services

${ }^{3}$ This is a term the writers use to refer to economy run by local communities with a classification level of Micro, Small \& Medium Enterprises (MSMEs).
} 
Such tough and resilient local economy is actually one of the efforts undertaken in order to face numerous business issues that led to the lack of progress in prevailing businesses. Bank Indonesia in a study recorded that internally speaking local economy is confronted with issues of limited investment, actors' low level of business knowledge, prevalence of unincorporated businesses, lack of proper business administration/management. Meanwhile, externally speaking local economy is faced with an unsupportive investment climate, lack of accessibility to both input market and product market, as well as continually changing market demand (LPPI and Bank Indonesia, 2014). All the issues above are intertwined and upon further examination they are ultimately caused by the impotence of the actors own spirit of entrepreneurship (Retnandari, 1999).

A response in addressing the various issues found in local economic development has been provided through the Participatory Appraisal of Competitive Advantage/PACA model (Meyer, 2003). PACA is a local economic development model that combines competitiveness concepts with the principles of rapid participatory appraisal in order to quickly identify and implement activities for stimulating local economy. The success of local economic development is founded on active participation, communication, and coordination among multiple actors. Local economic development is not to be entirely entrusted to paid professionals as the various stakeholders' motivations are the most significant key in local economic development. This is the model that serves as the bedrock of local economic development in the province of Central Java.

The PACA approach in Central Java was bundled in a cluster-based MSME development program. Numerous clusters have been developed in Central Java, in 2015 out of the 35 existing regencies/municipalities in the province there were 9,256 MSME (cluster) groups under the supervision of the Office for Cooperatives and MSME (Dinas Koperasi UKM Jawa Tengah, 2015).

One of the clusters that has, as of current, been witnessing successful development is the tourism cluster in Ponggok, Klaten. As a tourism cluster, its success is indicated by an exponential increase in the number of tourists visiting the area. Additionally, this cluster, which began operating in 2010, had succeeded in bringing in 72 thousand tourists in 2014. This amount had increased to 180 thousand visitors in 2015. Such extensive quantity of visitors had amplified the Village Original Income (Pendapatan Asli Desa - PADes) of Ponggok Village from a mere 30 million rupiahs per annum in 2010 into more than 4 billion rupiahs in 2015 (Laporan Kinerja Bumdes Tirta Mandiri, 2016).

Cluster Development in the Central Java region is one of the approaches implemented to address various issues impeding local economic development by using a comprehensive approach. The Ponggok cluster is one of the clusters that have been enjoying fruitful results as of current. It is indeed interesting to learn from the process of cluster model development implemented in Ponggok. This study is expected to provide lessons learned that may inspire other regions to develop their local economy. This article, thus, discusses the occurring process in developing the cluster, from its initial establishment to its management stage that had allowed it to reach continuous success till today.

\section{Cluster in Local Economic Development}

Local Economic Development (LED) is one of the instruments employed by a region to accelerate development in its area. According to Blakely and Bradshaw (2002) LED is a process in which local government and social organizations are involved to drive, stimulate, and maintain business activities capable of creating employment. With an emphasis on 
involvement/participation, this process requires creative local economic development in generating involvement. An appropriate approach is necessary to achieve such local economic development, and the PACA model is one of the local economic development models that prioritizes the rapidly-driven participation of actors in order to develop local economy (Meyer, 2003).

The PACA model of local economic development is founded on 3 basic principles, namely participatory, appraisal, and competitive advantage.

1. Participatory

PACA is a participatory approach that does not merely relate at the conceptual level. The PACA model of participation rests on two main points, namely: (1) Successful local economic development should be based on the active involvement of stakeholders relevant for local economic development or stakeholders who could create local economic development obstacles. An LED process should also be organized in a transparent manner and it must be managed in such a way that encourages more actors to be involved; (2) Successful local economic development involves a constructive relationship between the public and private sector, without any notion of positional hierarchy indicating superior and subordinate. The perspectives of the public and private may often differ, yet in terms of local economic development there are numerous aspects that can be integrated, for that dialog among actors on equal footing is a must. The definition of participation in this case is, thus, togetherness or convergence, not between that of a superior and a subordinate, but among colleagues of equal stature.

2. Appraisal

The core of PACA is a methodology that allows for rapid appraisal of local economic development. And it does not only develop its economic potentials, but also political aspects that encourages local economic development. Presuppositions on what is to be done, or what is required when collaborating with relevant stakeholders will be able to generate innovations that are favorable for all parties.

3. Competitive Advantage

The main target of the PACA approach is not to elaborate issues of obstacles and decreasing efficiency, but to seek or find opportunities that improve local business environment within a short period of time. PACA relates to Michael Porter's concept on location-based competitive advantage and the analytical concept of systemic competitiveness.

PACA will greatly develop given the support of a healthy local economic development environment. Another concept in local economic development that highlights the role of multiple institutions and the process it entails is the Hexagon model of local economic development approach (Meyer,2005). This Hexagon model explains 6 key variables that should be considered when developing local economy, namely: target group; locational factors; policy focus and synergy; sustainability; governance; and process management.

Once local economy starts to grow a method is required to manage the local economy to grow in a sustainable manner. A common economic concept will endure if the actors involved in the process could continually gain benefit from the mutually aspired development. Achievements of institutions based on cooperation/collaboration around the world indicate that mutual economic cooperation can be sustained if the actors involved were to gain benefit from their mutual efforts (Bantul REDs Team, 2010). This has been emphasized by the founder of the concept of people's economy, wherein 
maximum involvement of economic actors is highly encouraged so that economic growth would allow them to enjoy the results it generates (Sri Edi Swasono, 1983). Involvement in the process and gaining benefits from conducted activities form the basis of the notion of justice that is stipulated in the concept of economic democracy (Mubyarto, 1980).

One of the concepts that can be used to explain the continuous assurance of added benefit the actors may gain through local economic development is the concept of cluster development. The term cluster was actually developed by economic development experts to illustrate a collection of mutually linked companies that support each other (Porter, 2000). Such mutual support is subsequently manifested in the development of specialized knowledge and skills thereby creating infrastructure and supporting industries that enhance productivity in order to maintain the location's level of prosperity (Ketels, 2008).

When the cluster concept is used to explain local economic development then social and economic dependence are included in the cluster (Rocha, 2004). Within such interdependency, cluster members who mutually support and work together will create added values reflected in the reduction of costs for production and delivery of goods and services (Scott, 1998). It can be observed to this point that the key in cluster development of LED lies in the interaction and collaboration of various factors and stakeholders involved in developing the cluster.

Factors or variables that form the cluster and its interactions are varied among the cluster models. The Diamond model states that clusters contain four determining factors directed at industrial competitiveness and improving local economy, namely: (1) factor input conditions; (2) demand conditions; (3) related supporting industries; (4) firm strategy, structure, and rivalry (KyeongAe Choe and Brian Roberts, 2011).

Factor input conditions refer to existing variables that an industry cluster may already have such as human resource, capital, infrastructure (physical infrastructure, information, knowledge and technology, administrative infrastructure), and natural resources. Demand conditions relate to customer satisfaction and demand at the local, national, and global levels. Related supporting industries refer to availability of infrastructural support that can enhance efficiency and synergy within the cluster. Firm strategy, structure, and rivalry relate to strategic strength and the complexity of competition encountered. The model from the cluster develops 9 variables to improve cluster competitiveness (Cho, Dong-Sung and Moon, Hwy-Chang, 2003). The determinants of competitiveness comprise of eight internal elements and one external element. The eight internal elements consist of four physical elements (natural resources in possession, business environment, related supporting industries, and domestic demand covering the quantitative and qualitative aspects). The remaining four internal elements are workers, politicians and bureaucrats, entrepreneurs, along with managers and professionals. Meanwhile, external element is occurrences and opportunities that cover unexpected breakthrough, capital market fluctuation, movement of international demand, outbreak of war, and others.

Based on linkages among the factors found in a cluster, at least three typologies can be mapped out, they are network clustering, collaboration/partnership clustering, and satellite model clustering. The network clustering or the bottom-up model has its strength in the network maintained by the cluster initiators (Jhon Field (2003). The network is initially established as an informal network that subsequently develops into a structured and formal organization and ultimately becomes a large company or grows extensively and conduct various activities on behalf of the cluster network's members. This type of clustering is also known as bottom-up clustering as it starts from the bottom and it is initiated by the local companies themselves. The key of mutuality fostered in this cluster is entrepreneurship clustering that is oriented towards pure business. A cluster manager is nominated or derived from the cluster members, who are local business actors, and funding for their activities is unrestricted and may come from various 
sources. Continuity in this type of clustering is more definite, while from a political aspect, particularly in gaining local government support, it is relatively low. The main goal of network clustering or the bottom-up model is to develop initiatives and generate progress towards measurable objectives while concurrently seeking opportunities to achieve other results. This model is considered significant in the success of businesses, particularly at the onset of business development, and it functions as a source of information that can identify and discover business opportunities, and it can help to open financial access for the company.

Development of the partnership clustering or the top-down model is based on the partnership between the public sector, the private sector, and the community (Porter, 2000). The main feature of this clustering model is strong political involvement since the main actor originates from outside of the cluster members. This cluster is highly centralized and the cluster manager is usually nominated by the initiator and it heavily depends on public funding. This clustering model has been extensively implemented at both local and regional levels, and there is a cluster organization or institution established to provide a variety of services to cluster members, which include collaborative marketing, lobbying, sharing resources, research and development, human resource development, and public relations. The advantage of this model is that it substantially reduces business risks and costs. This is also beneficial for small companies to achieve economy of scale as a group when competing against larger companies for business and contracts.

The satellite model clustering is a cluster type initiated by big companies intending to engage in collaboration with small companies, consequently the small companies will be dependent of the large companies that spearhead the cluster. The organizational structure of such a model tends to be hierarchical and centralized.

\section{Study Methodology}

This study was conducted using the qualitative approach by carrying out in-depth exploration in the occurring process of local economic development. Data collection was, thus, carried out mainly through in-depth interviews and observation method. Observation was conducted to directly examine the Umbul Ponggok tourist site along with its activities and the communication process that took place among the stakeholders in managing this tourism village. In-depth interviews with actors involved in the development of Umbul Ponggok tourism were also carried out. Based on the interview results a thorough outline of Umbul Ponggok was acquired, starting from its historical beginnings, management model, and the challenges and obstacles it experienced during the development process and in maintain sustainability. Secondary data in the form of reports and other documents such as the Ponggok Village Mid-Term Development Plan were collected, processed and utilized to complement the analysis.

\section{Ponggok Tourism Village, Klaten}

The main tourist attraction in Ponggok village is a spring pond named Umbul Ponggok. The Umbul Ponggok Pond is a pool measuring 50 by 25 meters with an average depth of $1.5-2.6$ meters. The spring pond has existed since the period of Dutch colony 
and is one of the unique tourist attractions available. Umbul Ponggok's main draw is its water sports activities such as swimming, diving, and snorkeling, as well as the currently trending selfie photographs that can be taken underwater. Visitors can take selfies on site along with fishes of assorted colors, and a variety of photo props such as a bicycle, a vespa scooter, camping tent, television with PlayStation, and other properties.

The Umbul Ponggok Tourism Village, Klaten is a water-based tourism village. It has also developed at least 3 water-based potentials and has benefited much from them. Ponggok village has several fresh water springs that are actively utilized for village development, namely: Umbul Ponggok spring serving as a tourist destination; Umbul Sigedang spring utilized for mineral water production packaged by PT. TIV Danone Aqua Indonesia; Umbul Besuki and Banyu Mili springs. These fresh water springs not only flow through Ponggok village, but they also serve as the main water source for villagers living in Ponggok and its surrounding areas. The springs in Ponggok village flow southward to the Karanganom District and eastward up to the Ceper District and the water is used for field irrigation, fresh water fish cultivation, and drinking water. The abundance of water leaves a substantial number of villagers to pursuit their livelihood in the water-based sector of which among them are fresh water fish cultivation. The quantity of tilapia fish production in this village reaches \pm 4 tons per week, with product marketing not merely limited to around the Klaten Regency but reaching outside the regency. Another source of income for the residents there is working at PT Danone and being involved in Umbul Ponggok activities.

Ponggok village, with a land area of 77.225 ha, was formerly considered as a poor village. The location of this village is quite strategic as it is easily accessible from the Yogya

- Solo road. The distance from Ponggok village to the Yogya - Solo road is only $\pm 10 \mathrm{~km}$ of good asphalt road. This once poor village has now become an independent village as a result of the development of its water-based village potential.

Year 2002 was the start in utilizing the abundance of water resource available in the village. At the time, Sunarto, the head of the village, established a partnership with PT. Tirta Investama (TIV Danone AQUA Indonesia) and bestowed them with village treasury land that included Umbul Sigedang spring for mineral water resource. The advent of the water packaging factory had thus assisted the village in funding development activities. Ponggok village has consequently obtained a royalty fee of $0.25 \%$, which amounted to 125 rupiahs, per liter per month from water sales. As of today, the village's net income from the sale of water has reached 100 million rupiahs per month. The presence of PT. TIV Danone Aqua Indonesia has also been a blessing for the residents of Ponggok village, particularly in terms of opening up new employment opportunities. Currently, $40 \%$ of workers at PT. TIV Danone Aqua are people from Ponggok village.

The capital accumulated from the village's partnership with the company along with the support of UGM's community service program (KKN) and People's Economy Dashboard (Dashboard Ekonomika Kerakyatan - DEK) of the Faculty of Economy (FE), UGM had driven the subsequent village head, Mr. Junaedhi Mulyono, to establish a village- owned enterprise (Badan Usaha Milik Desa - BUMDes), named "Tirta Mandiri", tasked with managing potentials and developing Ponggok village owned business units. As of current, DEK FE UGM continues to be a partner of BUMDes "Tirta Mandiri”.

Ponggok village has been capable of not only providing its village with impressive village facilities and infrastructure, but also creating prosperity for its villagers through the BUMDes. The village administration and BUMDes have constructed a number of village facilities and infrastructure with incredibly significant development, among them is the village administration building fully equipped with supporting facilities and development of Umbul Ponggok water 
tourism attraction which exhausted \pm 4 billion rupiahs from the village budget. This process is expected to continue as stipulated in the Village Mid-Term Development Plan (Rencana Pembangunan Jangka Menengah Desa - RPJMDes) stating that up to the year 2020, the Ponggok Village Administration shall emphasize on programs of environmental design, household health and hygiene, and management of village potentials as a tourist destination with the slogan of "Ponggok Pasti Bisa" (Ponggok Surely Can).

Umbul Ponggok is essentially an existing natural resource. This spring pond has been managed as a source of water irrigation since the period of Dutch rule in Indonesia (1883). This Umbul had since remained as a source of drinking water and other water related purposes. As previously mentioned, in 2009, KKN UGM was carried out in this village and students along with the village apparatus began to develop this spring pond into a tourist destination. The abundance of water and its array of colorful fishes were the main attraction at the time. Nevertheless, this tourist site had not been able to attract much visitors.

In 2012, BUMDes Tirta Mandiri collaborated with the Diving Team of Universitas Gadjah Mada (UGM) and Yogyakarta Diving Community to use Umbul Ponggok as a fresh water snorkeling arena. These snorkeling activities were then uploaded on social media (Facebook, WhatsApp, Twitter) by several members involved in the activities. These uploads garnered extraordinary response which manifested in the throng of visitors coming to Umbul Ponggok. Ever since Umbul Ponggok has become a top tourist destination spot. Until today, tourism management there remains to be carried out under the BUMDes Tirta Mandiri.

The results Umbul Ponggok has currently achieved are increase in tourism visit and Village Original Income. Regarding visitor's quantity, in 2014 Umbul Ponggok was merely capable of attracting 72 thousand visitors, but in 2015 the number of visitors had reached 367,000. The immense number of visitors had consequently led to an annual increase in Ponggok village's PADes. In 2010, the amount of PADes collected totaled 30 million rupiahs, while in 2015, that figure had reached 540 million rupiahs.

\section{Umbul Ponggok Tourism Cluster}

Umbul Ponggok Tourism Cluster which is a part of Ponggok Tourism Village has enjoyed great success as a source of welfare to its residents. Based on elaborations in the passages above, determining factors leading to the success of this village in managing the Umbul Ponggok tourism destination have been identified. The factors are:

\section{Input Factor}

The input factor is variables that already exists in Ponggok village and they are owned by the village. This factor is a supporting variable in the development of the Umbul Ponggok water tourism village cluster, and there are two significant input factors identified, namely:

a. Umbul Ponggok Pond

Umbul Ponggok pond is unique since its bed is a spread of sand and stones. The clear pond water continuously flows and fish thrives freely making this pond very much like the sea.

b. Umbul Ponggok Tourist Attraction supporting facilities

A tourism area requires other infrastructural support. This area possesses all the necessary facilities (starting from parking lot, diving equipment, underwater camera and photographer, shops, stalls, and other amenities) that 
are all run by local villagers, who are either BUMDes employees or youth group and individual residents.

\section{Demand Factor}

The demand factor relates to two substantial factors which are source of demand and consumer's response to the provided services. From a perspective of visitors' origin, this cluster is not only visited by visitors at the local level (around the Klaten area) and the regional level (around Central Java), but it is visited by national and international travelers as well. As mentioned previously that in 2015 this destination was able to attract more than 600,000 visitors or an average of nearly 2,000 visitors per day. Regarding the provided services, it has been well documented that the visitors were satisfied with the services given. The following quote from an interview with a visitor illustrates their satisfaction visiting the attraction.

"having fun at Umbul Ponggok is really great, and when we wanted to take underwater selfies the technicians were really helpful and even the services provided by the staff were very friendly (interview result).

\section{The Role of Other Parties}

As mentioned above, there are several stakeholders involved in the development of Umbul Ponggok. Aside from the community and village administration having significant roles, there are a number of institutions that are recorded to be involved with the village, namely: Dashboard Ekonomika Kerakyatan (DEK) of the Faculty of Economy and Business (FEB) of Universitas Gadjah Mada (UGM); BNI Bank Klaten branch office; and Yogyakarta and UGM diving community. DEK FEB began conducting their activities as early as 2009 through the university community service program $(\mathrm{KKN})$ and the partnership still continues today. DEK provides assistance in general business management, BNI Bank of Klaten provides active support in terms of investment and human resource development, while the diving community actively participate in marketing and technical aspects.

\section{Management Strategy of BUMDes Tirta Mandiri}

Umbul Ponggok is managed by BUMDes Tirta Mandiri. The aim of this management development is to develop innovation and creativity. The management is, thus, directed towards two significant aspects, which are management administration and human resource development. BUMDes has been capable of implementing simple modern management principles in managing its businesses. Some of the management principles implemented in managing BUMDes are as stated below.

a. A sustainable and comprehensive monitoring system that is integrated with an evaluation process particularly relating to budgeting and financial standards, as well as budget implementation covering effectiveness, outcome, and added value of activities included in the budget.

b. An accounting system with simple administrative support sufficient for fulfilling accounting standards that are in line with existing regulations and a transparent and accountable reporting system.

c. BUMDes has an administrative system that is separate from the village administrative system in relation to finance and assets owned by the village and BUMDes respectively. 
d. A simple management structure that adapts to their needs, yet remaining pursuant to existing regulations and running according to each of the designated function with continuous improvement in professionalism.

Human resources development is carried out by organizing trainings, comparative studies, or internship at relevant institutions.

\section{Role of the Government}

In relation to the development of this area, the Klaten Regency administration had a crucial involvement wherein the regency has issued a legal basis which serves as a foundation for establishing the BUMDes, namely Klaten Regency Regional Regulation No. 20/2006 on Village-Owned Enterprise (BUMDes). This regulation has thus become the basis for the Ponggok village administration to establish the BUMDes as stipulated in the Village Regulation (Peraturan Desa - Perdes) No. 6/2009. In terms of implementation, however, the regional administration has no specific role to play. The assistance provided by the regional government is merely limited to general assistance regarding development of MSMEs throughout the entire regency in the form of trainings for MSME actors.

\section{Participatory-Based Accountable and Transparent Management Guarantees the Outcome}

The basic concept of local economic development rest on two important aspects, namely accomplishing development goals and local community involvement in utilizing local resources. Based on the collected data and information, it can be observed that the development of Umbul Ponggok tourism area has aptly fulfilled those basic principles of local economic development. Efforts of involving community participation in the implementation of economic development had undergone quite a long journey.

In the not too distant past, Ponggok was a poor village (one of the poorest in the Polanharjo District) and was always in a prolonged economic crisis. This resulted in many of its residents being burdened by debt to loan sharks and a large number were unemployed and decided to seek job elsewhere by leaving the village.

Given such conditions some villagers had initiated to help the community and the village administration to resolve their problems by developing Umbul Ponggok's water tourism. In its initial development, many villagers were not supportive and unconvinced that their idea would help them escape poverty.

The main concern of these doubtful residents was related to the water's function as a source of clean water activities essential to the villagers and the management system that would be implemented. Based on learning experiences they witnessed in other locations (areas), improper management of resources would not lead to more prosperity for its residents but trigger conflict among related parties instead. In this case, Pindul Cave is one of the actual conflict that had occurred in a community based tourism area (MAP UGM and Pusbindiklatren, 2013).

The initiators of tourism development continued their efforts of convincing the villagers to support their initiative of water tourism development in Umbul Ponggok. Intensive meetings with residents were often held at the Neighborhood Association (RT), Community Association (RW) levels, and in mosques or even by visiting villagers from door to door. These efforts were carried out to establish the community's trust that the Umbul Ponggok tourism development would not disrupt the residents' activities and that its management could be conducted fairly. The relentless communication efforts carried 
out by the pioneers had eventually bore fruit. The community had gradually begun to accept the idea of developing Umbul Ponggok tourism.

In 2009 the community service program (KKN) conducted by the Faculty of Economy students from UGM strengthened the existing ideas. As part of an education institution, KKN had provided support by strengthening community awareness and assisting in business management at the village level. These efforts had gradually produced fruitful outcome along with the village administration's willingness to take responsibility for managing the resources they plan to develop.

Through assemblies held at various levels of village governing bodies, it was ultimately agreed that management of village potentials would be implemented through the BUMDes. The aim of establishing BUMDes specifically covers 3 points: (1) empower economy of the people by facilitating the development of productive ventures villagers pursue; (2) provide open business opportunities and access to employment; (3) provide extensive and varied business ventures in line with village potentials, and according to the needs and capacity of the village community.

The establishment of Ponggok Village BUMDes Tirta Mandiri as a mutual decision did not mean all issues resolved. Some part of the community remained pessimistic towards the management of BUMDes. Negative sentiments grew leading to more residents feeling pessimistic that the BUMDes could make progress let alone bring about changes in the community's wellbeing. This was a result from the lack of BUMDes Tirta Mandiri activities for 7 months in 2012. However, at the end of 2012, the village executive, the Village Planning Board (Badan Perencanaan Desa - BPD), and the community held an assembly to elect new BUMDes organizers.

During the assembly the Ponggok village head stressed that the village potentials should provide benefit to the village itself. A manifestation of self-management by the village community can be observed in the various ways they pursue in managing the activities and resources they possess. The management of Umbul Ponggok is basically under the coordination of BUMDes Tirta Mandiri, despite the extraordinarily high level of community involvement.

The initial form of community involvement was obviously by employing village residents to become BUMDes employees. In managing Umbul Ponggok, BUMDes is responsible for ticketing, equipment maintenance, safety, parking, sanitation, and investment. However, not all those activities are conducted by BUMDes as some are handed over to the community under the coordination of BUMDes.

Regarding parking, this is left to residents who own parking areas, as they would provide parking and become parking attendants themselves. As for other supporting facilities, there are MSMEs that own individual businesses, such as food stalls and equipment for rent. Photography props rental, in particular, is managed directly by the Ponggok Village Youth Organization group, while snorkeling equipment rental is managed by BUMDes Tirta Mandiri. These steps were taken by the Ponggok village administration in order to accommodate unemployed youths in the village who were unable to work as BUMDes Tirta Mandiri staff.

There are three bath and toilet facilities provided in the Umbul Ponggok tourism area, and the management of these facilities is carried out alternately by the six Community Associations (RW) in Ponggok village according to a designated schedule. The proceeds obtained from managing these facilities would be received and recorded as income for the 
RW's treasury and would subsequently be used to support activities carried out in the respective areas.

Another form of community participation observed in Ponggok is the BUMDes' innovation of issuing shares that villagers can purchase. Through shares ownership, residents can directly enjoy the growth of BUMDes without being actively engaged. The shares are offered with the highest value of 5 million rupiahs, a medium value of 1 million rupiahs, and small share value of 100 thousand rupiahs. Such classification of shares is meant to accommodate all the residents in accordance with their respective financial capacity. So, not only affluent residents would be able to purchase these shares, but those with low income can purchase them as well. Additionally, these shares also serve as the community's tool for controlling the performance of BUMDes Tirta Mandiri.

The community's control function is structurally afforded to the Monitoring Agency (Badan Pengawas BP) who are elected through assemblies at the RT/RW levels. Every $\mathrm{RT} / \mathrm{RW}$ has their representative in the BP committee. In addition, an evaluation meeting is always held every semester involving the BUMDes Tirta Mandiri Advisory Board, the Monitoring Agency, and the investors (shareholders). As of current, the profit sharing mechanism employed in the management of Umbul Ponggok water tourism village cluster depends on the amount of profit BUMDes Tirta Mandiri earns, and it is shared based on the value of shares each individual owns. Additionally, the internal management system that has been implemented using the 4 principles of modern management mentioned above has resulted in a transparent and accountable business performance.

Participation and guarantee of good business management undoubtedly ensure common welfare. As previously mentioned, Umbul Ponggok has succeeded in generating a substantial source of income for the village, thereby indirectly allowing the village community to enjoy the fruits of labor from the development of Umbul Ponggok implemented by the village. The villagers are also able to directly enjoy the current presence and progress of Umbul Ponggok either through their direct involvement in various activities or through the shares they own.

Regarding community participation, there are independent MSMEs around the Umbul Ponggok area that aim to reap profit from the throng of visiting tourists. Food sellers or souvenir vendors are those who also enjoy the development of this tourist area. The recorded observation results indicate that they used to enjoy the areas growth, it has however gradually declined. The rise in ticket price is assumed to be the reason for this decline as their earnings decreased along with the increase in the attraction's entrance fee. Another aspect we focus on in this study is the area's support and capacity to accommodate all the activities that continue to progress and grow rapidly. The extremely high number of visitors results in more congested traffic flow thereby requiring broader open areas for parking or other purposes. The residents currently begin complaining about the safety of their children while conducting activities on the streets such as heading to school. The crowded traffic becomes a point of concern for the residents over the safety of their children.

The analysis on the development of Umbul Ponggok, Klaten has led to a clear conclusion that the involvement or participation of multi stakeholders, particularly the local community as the main actor, is essential in order to enable local economy to grow. The involvement of external parties is merely as supporting partners in resolving all issues and challenges the village confronts. In terms of economic activity, the subsequent necessary step is to be able to understand the need of consumers. An accountable and transparent management is internally the basis in strengthening the trust that has been established and 
fostered by the entire community. Ultimately, regulatory and infrastructural support would strengthen the development of economic venture in this village. A diagram which summarizes the involvement of various parties in the development of Umbul Ponggok cluster is presented below.

\section{Diagram 1}

Stakeholder's Involvement in the Development of Umbul Ponggok, 2018

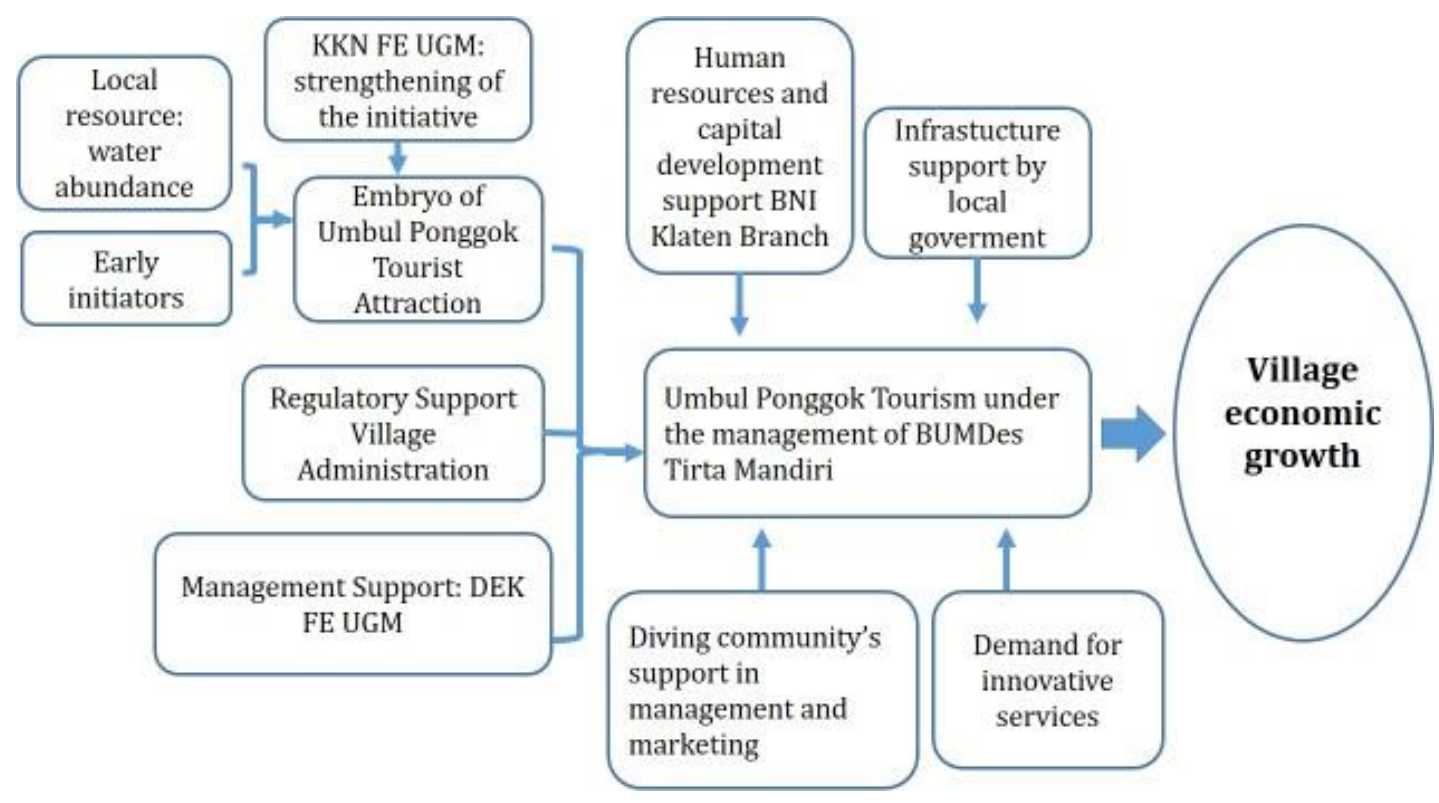

Source: Data analysis result

Nevertheless, the seemingly perfect local economic development is not without its problems. When an activity becomes successful in Indonesia, it is not uncommon for it to face external issues. A successful community will be awarded and gain recognition from higher level of government. Such recognition, on the one hand, provides energy motivating its members to be more full of zeal. Yet, on the other hand, an award or 
recognition with all the due process and procedures it entails takes up a substantial amount of energy. When a local economic development activity has gained recognition and the information has been disseminated and becomes widely known, this will attract the interest of other regions to conduct study visits to learn from the success they have achieved. Regardless of the positive aspects these visits have, they also require a considerable amount of energy. In addition to that, there are also requests from other regions or even higher level of government bodies for village representatives to deliver a speech or share their knowledge and experiences. If such activities were not managed properly, they may ruin the hard efforts stakeholders put into the organization instead. Another challenge to confront in light of the success in Umbul Ponggok's development is the fact that there are some residents who feel they have yet to enjoy the occurring development. As previously mentioned, there are some part of the community who still harbor such feeling.

Of no less importance is the task of managing the village's capacity and support facilities to anticipate the progressively increasing number of visitors. Such support and capacity does not only refer to the physical aspects but to the social as well. There have been numerous cases of tourism areas that were developed haphazardly and they have instead turned into social problems originating from moral change prevalent in the community.

\section{Closing}

Umbul Ponggok has succeeded in becoming a source of livelihood for the community. An accountable and transparent management system coupled with community participation that is supported by various other stakeholders has turned the region into one of the most significant tourist destinations in the area surrounding Yogyakarta.

Currently, there have not been any challenges encountered that weakened the development of Umbul Ponggok. However, indications of future problems arising are quite obvious. The sources and energy taken up for ceremonial activities, the issue of village capacity and supporting facilities, and the feeling some villagers have that they have yet to gain any benefit are among these challenges.

The organizers should, therefore, develop a more resilient environmental management. The community's incapability to enjoy the existing growth is mostly afforded to their lack of capacity. The organizers should, thus, strive to accommodate them by carrying out capacity building activities such as providing trainings that can result in more innovative and skilled human resources.

Regarding the energy spent on ceremonial events and activities, Ponggok village administration and the BUMDes Tirta Mandiri management should have a schedule of priority. Moreover, a growing business requires professional management, thereby development of human resources is again essentially required. The innovations they generate should not only relate to products and services but to institutional management in its entirety as well. The issue relating to village capacity and support facilities must be anticipated by all community members. Development that is implemented within the guided path of social capital will endure as it will be capable of controlling development from progressing negatively. Social capital is a noble aspect and character of the community. If existing social capital were to be developed as a basis for decision-making process, any progression towards negative tendencies should be preventable. 


\section{References}

Blakely and Bradshaw (2002). Planning Local Economic Development: Theory and Practice

Cho, Dong-Sung dan Moon, Hwy-Chang (2000). National Competitiveness: A NineFactor Approach and Its Empirical Application. Journal of International Business and Economy. Fall 2000: $17-38$.

Hector O, Rocha. (2004). Entrepreneurship and Development: The Role of Clusters Small Business Economics, Vol. 23, No. 5 (Dec., 2004), pp. 363-400.

Published by:

Springer. http://www.jstor.org/stable/40229373.Accessed : 09-06-2016 18:18 UTC.

Ketels, C.H.M. and Memedovic, O. (2008)_From clusters to cluster-based economic development, Int. J. Technological Learning, Innovation and Development, Vol. 1, No. 3, pp.375-392.

Kyeong Ae Choe and Brian Roberts (2011). Competitive Cities in the 21st Century: Cluster-Based Local Economic Development. AusAID

LPPI and Bank Indonesia, 2014, Profil Bisnis Usaha Mikro, Kecil dan Menengah, Lembaga Pengembangan Perbankan Indonesia MAP UGM dan Pusbindiklatren, 2013, Kasus Konflik dalam Pengembangan Kawasan Wisata Goa Pindul, Materi Kuliah Diklat Jenjang Fungsional Perencana Tingkat Madya tahun 2013

Meyer-Stamer, Jorg. (2003), Participatory Appraisal of Competitive Advantage (PACA): Launching Local Economic Development Initiatives, Mesopartner Working paper

Meyer-Stamer, Jorg. (2005). The Hexagon of Local Economic Development and LED in South Africa. Mesopartner Working paper

Mubyarto dan Boediono, 1980, Ekonomi Pancasila, Bagian Penerbitan Fakultas Ekonomi, Universitas Gadjah Mada Porter, E, Michael. (2000). Economic Development Quarterly, Vol. 14 No. 1, February 2000 15-34 @ 2000. Download: Sage Publications, Inc.Research and Practice. Location, Competion, and Economic Development: Local Clusters in a Global Economy

Retnandari, Nunuk Dwi. (2009). Kemiskinan Dan Usaha Mikro, Kecil dan Menengah. Dalam Jurnal Populasi Volume 19 nomor 1 tahun 2009. Pusat Studi Kependudukan 
dan Kebijakan UGM.

Sri Edi Swasono, 1983, Koperasi di Dalam Orde Ekonomi Indonesia, Salemba

Scott (1998, p.87), Charlie Karlsson (2008:85). Handbook of Research on Cluster Theory

Tim REDs Bantul, 2010, Pendidikan dan Latihan Regional Economic Development Supports, Kerjasama Pusat Pembinaan Pelatihan dan Perencanaan Bappenas dan Magister Perencanaan Kota dan Desa UGM 